\title{
THE OCCURRENCE AND ORIGIN OF SOME BOG IRON DEPOSITS IN THE DISTRICT OF THUNDER BAY, ONTARIO.
}

\section{ELWOOD J. MOORE.}

While engaged in making an examination of some bog iron deposits in the district of Thunder Bay, Ontario, certain observations were made which may add something to our knowledge of the occurrence and origin of bog iron. As a detailed account of these deposits has already been given, ${ }^{1}$ the present article will be restricted to those factors which bear upon the nature of the occurrence and origin of the iron.

The geological conditions in the region are similar to those described for the bog iron regions of Quebec and Sweden. The area is drift-covered and is situated in an Archean region where relief is low and the physiographic conditions cause sluggish and meandering streams, which here and there expand into small, swampy lakes. A heavy blanket of vegetation in the form of labrador tea and sphagnum moss covers the area and the slow movement of the water and the large supply of vegetation combine to produce two factors favorable for the production of bog ore, viz., an abundance of organic acids and plenty of time for them to act upon the minerals occurring in the drift.

\section{HOW THE IRON OCCURS.}

The iron occurs in both the ferrous and ferric conditions. and as a combination of the two forms. The ferrous form exists in the state of a greenish salt, or salts of the protoxide, and the ferric form as the common hydrous oxide, limonite. The ferrous salts are in all probability the sulphate and silicate, chiefly the latter in combination with some organic salt or salts. The combination of the two oxides gives a small amount of magne-

${ }^{1}$ I8th Rept. of the Bureau of Mines, Ontario, I909, pp. I80-I95. 
tite which doubtless has been deposited in the bog as a clastic sediment, as appearances lead one to that conclusion. It occurs in very small fragments which can readily be isolated with the magnet.

No carbonate of iron was detected, though special search was made for the salt because of the interest which is attached to it in the origin of the pre-Cambrian and other ores. According to Julien ${ }^{1}$ the carbonate of iron is not formed in a bog near the surface, at the present day. It is, however, occasionally observed in bogs a short distance below the surface, when the decay of vegetable matter gives rise to carbon dioxide and where there is not a sufficient supply of oxygen to form the soluble humates with organic substances. Messrs. Cameron and Robinson ${ }^{2}$ found by experiments that the ferrous carbonate was precipitated from a solution of a ferrous salt by an alkaline carbonate, but no definite ferric carbonate could be found to exist. They also found that under certain conditions, e.g., when precipitated from boiled water, the ferrous carbonate was dirty green in color, and this suggested that some of the greenish salt mentioned above might be the carbonate, but none of the tests made showed any of this salt.

The limonite occurs in red, brown and yellow colors and forms either soft or hard, bedded masses, concretions, slimy mud or cement in sand. In the mud there is usually more of the ferrous salt than the ferric because the organic material, by formation of carbon dioxide, prevents the oxidation of the material carried into the bog in the ferrous condition and even reduces some of the ferric to the ferrous salts. This reducing action may readily be observed along the shore of the lakes where vegetable matter is present. Here the brown limonite concretions which have a thickness of eight or ten inches, become gradually dissolved away in the lower layers of the deposit and changed to a greenish salt. The gradual dissolution of the concretions may be observed with increasing depth and this condition is similar to that which is

${ }^{1}$ A. A. Julien, "The Geological Action of the Humus Acids," Proc. Amer. Assn. for the Adv. of Sci., Vol. 28, p. 403.

${ }^{2}$ Journal of Physical Chem., Nov., I908, pp. 511 and 523 . 
found in the bogs of Quebec. ${ }^{1}$ This greenish salt readily turns red on heating, through oxidation to hematite. As some manganese occurs in these deposits, a portion of the black and greenish colors is no doubt due to its presence in different forms.

An analysis by Mr. N. L. Turner of the yellow limonite which formed a layer about four inches thick, in water two feet deep gave :

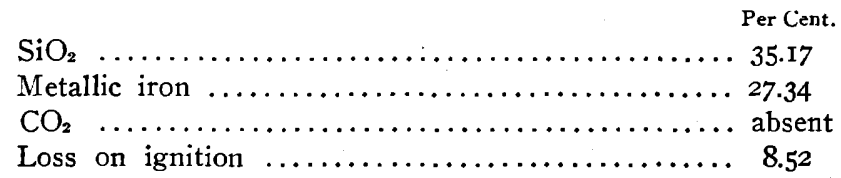

\section{CONCRETIONARY DISCS OF ORE.}

The most frequent occurrence of the iron is in the form of concretions, which assume various shapes, and possess a roughly spiral structure. To one used to camp life the disc-shaped forms immediately suggest dried apricots, while some of the forms more irregular in shape and more nearly equi-dimensional, strongly resemble dried prunes. The larger ones are usually concave and cake-shaped. They vary in size from half an inch to three inches in diameter and from one quarter to one half inch in thickness. These concretions are much smaller than the large ones found in Quebec or in New Brunswick, where, Chalmers $^{2}$ states, the larger cakes have a diameter as great as from two to three feet. They occur along sandy shores of the lakes, in shallow water, and extend a distance of two hundred yards from shore, but few of them were found in water more than two feet deep. They apparently owe their origin, to a considerable extent, to the presence of sand which forms nuclei for centers of crystallization. There is no doubt that some close connection exists between the origin of these concretions, the movement of sand by the waves and the depth at which the limonite will harden. It was observed that the iron was practically confined to the northern portions of the lakes and mostly to points or spits built by shore currents. This seemed to be

1 "Geology of Canada," I863, p. 5 II.

${ }^{2}$ Canadian Geological Survey, I882-84, p. 46 G. G. 
explained by the fact that the streams carrying the iron nearly all entered the lakes towards the north end and the prevailing winds in summer, when the iron solutions are doubtless most concentrated because of evaporation of water and increased activity of organic acids through the growth and decay of vegetation, blow from a southerly direction. Precipitation would then be aided by the rolling of the sand grains and it was found that scarcely any iron occurred where the beach was not sandy.

In the bottom of the lakes the distribution of the deposits was very irregular, as six or eight feet of iron-bearing slime occurred in the deeper water, in some places a thin layer of concretions in the shallow water, beginning where the mud left off and in other places yellow limonite occurred in shallow water. There was usually along the shore a bed of soft limonite and sand mixed with broken concretions, forming a layer from one to ten inches in thickness, and this layer was capped by a thin one of intact concretions. In the lower portion of the layer of broken concretions a green salt was generally conspicuous.

When the water in the lakes is low in the dry season considerable areas of concretions become exposed to the atmosphere and piled up by the waves along the water's edge. This deposit thins towards the lake and also landward.

A thin section was made from one of these concretions and another specimen was ground to a smooth surface, so its internal structure could be seen under the microscope. An examination of these specimens showed an opaque reddish-brown mass, which was not homogeneous, although no distinguishing feature beyond a finely porous condition, could be detected. In this mass were numerous angular, subangular or rounded fragments of quartz and a few of feldspar. There seemed to be no definite regularity in the orientation of the longer axes of the fragments, although in one case a roughly concentric arrangement could be observed. They were arranged either in bunches or as individuals scattered through the limonite groundmass. An analysis of some of these concretions made by Mr. N. L. Turner gave: 


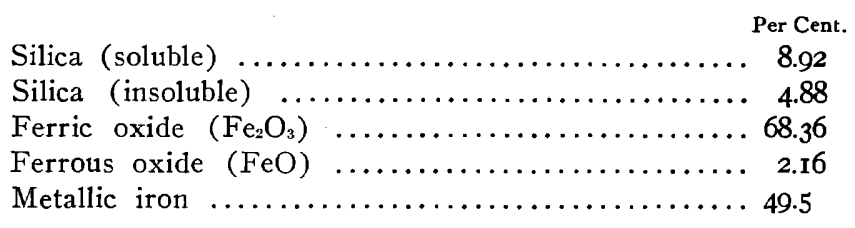

\section{SOURCES OF THE IRON.}

On entering this bog iron district a few conditions attract the attention of the observer. The chief of these are the unusually large muskegs, with their meandering streams and great quantities of vegetable matter, the presence everywhere of the sandy drift which apparently contains so little iron, and the red streams which deposit iron in the lakes and on almost every object they touch. The sand, which is the principal rock over which the waters flow, is made up chiefly of quartz and feldspar, the former devoid of iron and the latter also barren except for a little which may in some cases exist as coloring matter. Besides these two minerals there are minor amounts of biotite, hornblende, magnetite, pyrite, ilmenite, pyroxene and other iron-bearing minerals. Although the greater portion of the sand has come from the Laurentian granite, a considerable amount must have come from diabase and gabbro, so widely distributed to the north, and from the Keewatin iron-formations which have suffered so much erosion. Besides these sources, there is the probable source from previous bog deposits which were eroded by the glacier and their contents mixed with the sand. A microscopic examination of the sand showed that iron exists everywhere as a thin coating on the grains, which becomes red and much more conspicuous on heating, by the formation of the red oxide.

However inadequate the sand may appear as the source of the iron, it is the only rock which can furnish it.

TRANSPORTATION OF THE IRON BY WATER.

Regarding the quantity of iron in solution at any time, a few analyses of water collected from the streams and lakes by the writer and analyzed by Mr. S. J. Lloyd, are of interest. On account of the difficulties connected with the transportation, the 
quantities of water collected were small, and although the amount of iron present was quite sufficient for accurate determination and silica and manganese were found to be present, it was not possible to determine accurately the percentage of the two latter and carbon dioxide could not be found. There was so much iron in the water that in every case floculent iron hydrate precipitated from apparently clear water, after standing a few days in corked bottles. In one case there was enough of the precipitate to almost cover the bottom of the bottle.

To find, if possible, the relation existing between the proportion of iron carried by the'streams and that contained in the lake waters, samples were collected from the most easterly of the Little Bear lakes, near the point where the most iron was precipitated, and from the main creek entering the lake. This creek rises in a large muskeg to the northeast, and the stones in the bed of the stream are red with iron oxide.

Analysis (no. I) of the water from this stream showed: .06I gramme $\mathrm{Fe}_{2} \mathrm{O}_{3}$ per liter.

Analysis (no. 2) of the water from the lake showed: .056 gramme $\mathrm{Fe}_{2} \mathrm{O}_{3}$ per liter and a trace of manganese.

These analyses indicate that a loss of iron occurs almost as soon as the water enters the lake and no. I indicates still further that the stream was carrying ferric oxide at the rate of about one eighth of a pound to a ton of water. When one considers that this stream was about three feet wide and four inches deep and flowed at a moderate velocity, an estimate may be made of the amount of iron which would be carried by it in the course of a season. It is stated that in Lac-a-la-Tortue, Quebec, paying quantities of bog ore have been obtained from areas completely exhausted eight or ten years previously, ${ }^{1}$ and that the ores are renewed in the lakes of Sweden in twenty-five years.

Three samples were collected from the waters in the vicinity of Hematite Lake and the following analyses obtained. The first analysis (no. 3) was taken from the creek which flows from a small lake and near the outlet of the lake. It yielded .047 gramme $\mathrm{Fe}_{2} \mathrm{O}_{3}$ per liter. To ascertain the effect produced upon

${ }^{1}$ P. H. Griffin, Amer. Inst. Min. Eng., Vol, 2r, 1892-3, p. 974. 
the stream by flowing through more than two miles of peat and sand to Hematite Lake, a sample was collected from the stream near the lake and the analysis (no. 4) with .045 gramme $\mathrm{Fe}_{2} \mathrm{O}_{3}$ per liter, instead of showing an increase, as was anticipated, showed a slight decrease. This decrease might be due to the fact that the sands along its bed had already been thoroughly leached of their iron and the evaporation of water, combined with the oxidation of the iron, produced precipitation instead of solution.

Analysis No. 5 showing .02I gramme $\mathrm{Fe}_{2} \mathrm{O}_{3}$ per liter was stated by the analyst to be for some reason a little uncertain. However, it represents approximately the proportion of iron carried by the stream draining Hematite Lake, as the sample was collected from the stream near the outlet. Comparing this analysis with that of the water entering the lake, it will be seen that a considerable loss is experienced in the lake water, but about half of the iron which enters the lake passes on with the outflowing stream.

\section{SOLVENTS FOR THE IRON.}

It is generally agreed that plants are the chief agents in producing chemical action in the formation of bog iron. Small amounts of iron may be carried as ferrous or ferric sulphates derived by the oxidation of pyrite in the rocks but this quantity must be comparatively small, considering the small amount of sulphur in the deposits, compared with that which is derived by the action of organic acids on the iron-bearing silicates. The action of these acids is well described by Julien ${ }^{1}$ in the article already cited and he gives so many examples of the action of these acids, that their importance seems to be fully demonstrated. They are capable of dissolving and freeing sufficient silica to supply the quantity of soluble silica found in bog ores. This quantity varies from almost nothing to over 20 per cent. and in an analysis of concretions already given in this paper the soluble silica amounted to 8.92 per cent.

The organic acids associated with the formation of bog ores

${ }^{1}$ A. A. Julien, Proc. Amer. Assn. for the Adv. of Sci., Vol. 28, 1875, pp. 3II-4IO. 
include, among others less common, crenic, apocrenic and humic acids and of these the crenic compounds are probably the most active agents in the solution of minerals. Probably the best illustration of the action of these acids in the formation of ores, is furnished by the chemical experiments of T. Sterry Hunt, ${ }^{1}$ by 'which he showed that a sample of bog iron ore contained I5.OI per cent. of organic acids, crenic and apocrenic.

The action of carbon dioxide is an important factor in the weathering of minerals, but unless it is accompanied by other organic constituents its action is comparatively small. Professor Ossian Aschan ${ }^{2}$ claims that organic acids, rich in carbon dioxide, act upon rocks in a chemical manner, and as soon as they have freed some bases, such as potassium, magnesium and iron, certain bacteria are able to begin work and aid in the solution of the minerals by feeding upon the humates developed from these bases. As a result of the action of these bacteria the iron humates are decomposed and finally give up the iron in the form of limonite.

\section{PRECIPITATION OF THE IRON IN THE BOG.}

The small amount of ferrous sulphate which is carried into the bog in solution can readily be precipitated by calcium carbonate which is commonly present in solution and the result would be calcium sulphate and ferrous carbonate: $\mathrm{FeSO}_{4}+$ $\mathrm{CaCO}_{3}=\mathrm{CaSO}_{4}+\mathrm{FeCO}_{3}$, if it were not for the oxygen in the air. But as the oxygen of the air is always present at the surface of the bog lakes, the ferrous carbonate is not formed, and instead of it the ferric hydrate results thus: $2 \mathrm{FeSO}_{4}+2 \mathrm{CaCO}_{3}$ $+3 \mathrm{H}_{2} \mathrm{O}+\mathrm{O}=2 \mathrm{CaSO}_{4}+\mathrm{Fe}_{2} \mathrm{O}_{3} \cdot 3 \mathrm{H}_{2} \mathrm{O}+2 \mathrm{CO}_{2}$. Or it is more likely that the ferrous sulphate oxidizes first to ferric sulphate and the following equation represents the reaction: $\mathrm{Fe}_{2}$ $\left(\mathrm{SO}_{4}\right)_{3}+{ }_{3} \mathrm{CaCO}_{3}+{ }_{3} \mathrm{H}_{2} \mathrm{O}={ }_{3} \mathrm{CaSO}_{4}+\mathrm{Fe}_{2} \mathrm{O}_{3} \cdot 3 \mathrm{H}_{2} \mathrm{O}+3-$ $\mathrm{CO}_{2}$. The limonite thus formed collects as a thin film on the surface of the water, to sink later or become collected on objects along the shore. Such a thin film may be seen in almost any

1 "Geol. of Canada," I863, pp. 512-13.

${ }^{2}$ Zeit. für prak. Geol., 1907, pp. 56-62. 
region where a little stream seeps out of a bank where pyrite is present and it may also be seen where organic material is plentiful and in contact with crystalline rocks. The oxidizing influence is not entirely confined to the surface especially when the water is disturbed by the wind.

The action which takes place when the iron humates, $i . e$., the iron salts of the organic acids, reach the bog lakes where they become exposed to oxidizing influences, is rather complicated and not fully understood. It is considered, however, that these salts become oxidized and the insoluble limonite results. It is supposed, as already pointed out, that bacteria play some part in the freeing of the iron hydrate from solution, by the breaking up of the humates.

There are certain physical forces which also appear to influence the precipitation of the hydrate. The association of the iron with sandy beaches and the development of the deposits on certain portions of the lake are striking features. The sand grains doubtless serve as nuclei about which crystallization takes place and after some iron has been deposited the force of crystallization causes a further precipitation. This influence of the presence of iron is illustrated in bog iron regions where all the pipes used for the transportation of water become heavily coated with this compound.

The winds which tend to blow from about the same general direction during the summer, when the iron solutions are the most concentrated and likely to produce a maximum precipitation, drive the water toward the northern and eastern sides of the lake. When the waves are continually passed to and fro over the concretions, already formed, precipitation will be aided by chemical affinity and the movement of the water will also bring about more perfect oxidation of the water and thus of the iron humates and cause precipitation of the oxide. These various forces tending to deposit the iron, act in a cumulative manner by increasing precipitation, because of the presence of iron already precipitated, and by building out those spits or points where greatest accumulation occurs, so that the currents along shore tend to converge at certain points and make further deposits. 
Examples were seen in the field, of the influence which the direction of the shore currents had in producing deposits, as these commonly occurred where a current drifted along a sandy point.

There is one other factor which may be mentioned, as probably having a small influence on the formation of the concretions. When examining the deposits on the Little Bear lakes, it was found that a person wading out into the water suddenly experienced a very sudden change in the temperature of the water at a short distance from shore, although the wind was blowing at the time and to all appearances the water was pretty well disturbed. The point at which this change occurred was just about the line where the concretions ceased to form on the bottom of the lake and the water became only a little deeper. The cause of this difference in temperature was attributed to the great effect of the reflection of the sun's rays by the sand of the lake bottom, where the water was shallow. The question which arose on making this observation was whether the increased temperature had any influence on evaporation and concentration of solutions and whether the greater amount of light dispersed through the water might have any influence in dehydrating and hardening the limonite.

In the past there has been considerable speculation concerning the cause and process of the hardening and dehydrating of limonite. The observations of W. Spring ${ }^{1}$ are interesting in this connection. He states that iron hydroxide spontaneously loses its water if the iron is not combined chemically with some other substance. The yellow ochre color would thus indicate the presence of: $\mathrm{Al}_{2} \mathrm{O}_{3}, \mathrm{CaO}, \mathrm{MgO}$, etc.

Wittstein ${ }^{2}$ found that if iron hydrate were left for several years under water at ordinary temperatures, it dehydrated and became crystalline. It is also stated that organisms may dehydrate limonite. Spring concludes that iron hydrate is thus not a stable compound and gives up its water when it is not in chemical equilibrium with other oxides.

${ }^{1}$ W. Spring, Neues Jahrbuch für Mineralogie, etc., Band I, I899, pp. 47-62.

${ }^{2}$ Vierteljahresschrift für Pharmacie, r, p. 275. 